\title{
Effect of stocking density and different diets on growth of Percula Clownfish, Amphiprion percula (Lacepede, 1802)
}

\author{
João Chambel ${ }^{* \dagger}$, Vera Severiano ${ }^{\dagger}$, Teresa Baptista, Susana Mendes and Rui Pedrosa
}

\begin{abstract}
The aim of this study was to evaluate the influence of stocking density $\left(0.5,1,2\right.$ and 3 fish $\left.L^{-1}\right)$ and commercial marine fish diets (diet A, B, C and D) over four months on specific growth rate, condition factor, percentage without anomalous pigmentation (partial or total lack of white bands -miss-band) and survival of juvenile Amphiprion percula. Results showed that at 0.5 fishL $^{-1}$ densities induced the best survival (100\%) and also the maximum percentage of fish without miss-band ( $58.33+/-4.417 \%)$. The maximum SGR was obtained for the $0.5 \mathrm{fishL}^{-1}(0.459 \pm 0.023 \% \mathrm{~cm} /$ day). However, the best condition factor $(2.53+/-0.27)$ was achieved for 2 fish $\mathrm{L}^{-1}$ densities. There were no significant differences in survival (68.9 to 84.5\%), fish without miss-bands (18.03 to 26.92\%) and condition factor (1.92 to 2.1) among diets during the experimental period. On the other hand, diet C (with $41 \%$ crude protein) supported the best SGR $\left(0.485 \pm 0.001 \% \mathrm{cmday}^{-1}\right)$.

The results suggested that stocking density are critical and more relevant when compared with the different diet tested, namely on specific growth rate, condition factor, the miss-band and survival of juvenile percula clownfish. This study has particular significance with regards to anemonefishes husbandry in terms of survival and production efficiency.
\end{abstract}

Keywords: Amphiprion percula; Anemonefishes; Stocking density; Nutrition; Ornamental fish

\section{Introduction}

The marine ornamental industry has grown in last years. However is projected that less than $10 \%$ of marine animals sell in the world are originate from captive production. During last decades the unsustainable capture of wild organisms to the ornamental trade have serious consequences with the degradation of habitats and populations of tropical and subtropical marine fish are being depleted worldwide to supply increasing demands of the aquarium industry (Moorhead and Zeng 2010; Chambel et al. 2013; Araujo et al. 2014). In line with this view, it has been recommended the use of specimens produced in captivity. This approach reduces the utilization of natural resources, is therefore substantially more sustainable than relying on wild-caught organisms and may even be used to restore depleted ornamental populations

\footnotetext{
* Correspondence: joao.chambel@ipleiria.pt

${ }^{\dagger}$ Equal contributors

MARE - Marine and Environmental Sciences Centre, ESTM, Instituto

Politécnico de Leiria, 2520-641 Peniche, Portugal
}

(Ziemann 2001). One of the main problem with the production of marine ornamental species is optimize production in order to compete with less expensive specimens collected from the wild (Calado 2006; Jamabo and Keremah 2009; Chambel et al. 2014). The anemonefish, Amphiprion percula is a tropical coral reef fish belonging to the family Pomacentridae fishes and anemones and sub family Amphiprioninae. Are found in warmer waters in the Pacific Ocean, Indian Ocean, off northwest Australia, southeast Asia and Japan and they are one of the most popular marine ornamental fish (Dhaneesh et al. 2012b). This species, as other of Amphiprion species, is of the few marine ornamental species produced in captivity, unfortunately, anomalous pigmentation, consisting of partial or total lack of white bands (miss-band) is a common problem in the production process of this species (Avella et al. 2010). Pigmentation abnormalities reduce the market of fish so, solve this problem represent an important challenge to the ornamental aquaculture industry (Copeman and Parrish 2002).

\section{实}


Diet and stocking densities are two major factors in aquaculture influencing growth, welfare, and health (Ellis et al. 2002; Alcorn et al. 2003). Feed costs make up a large part of the total fish production costs. The optimization of growth rates and feed efficiency depends on the quantity of food delivered, feeding method and feeding frequency, quality and composition of the diet (Gélineau et al. 1998; Yang et al. 2003; Erondu et al. 2006).

Stocking density directly influences survival, growth, behaviour, water quality and feeding. In aquaculture, stocking density is the concentration which fish are stocked into a system (Gomes et al. 2006; de Oliveira et al. 2012). Generally, increases in stocking density results in directly increase on the stress condition, causing a reduction in growth rate and food utilization (Sharma and Chakrabarti 1998). On the other hand, in very low densities, fishes may not form shoals and may feel unprotected.

Consequently, identifying the optimum stocking density for a species is a critical factor not only to enable efficient management and to maximize production and profitability, but also for optimum husbandry practices (Leatherland and Cho 1985; Kristiansen et al. 2004; Rowland et al. 2006).

The goal of this study was to evaluate the influence of stocking density and the influence of four commercial diets for marine fish, on growth, condition factor, percent of fish without anomalous pigmentation, and survival of juvenile $A$. percula.

\section{Material and methods}

The experiment was carried out at the Ornamental Aquaculture Laboratory of Polytechnic Institute of Leiria. A total of 530 Amphiprion percula juveniles averaging $142.1 \pm 2.8 \mathrm{mg}$ and $1.920 \pm 0.01 \mathrm{~cm}$ (mean \pm SEM) were obtained on a local producer of ornamental fish. Clownfish were initially stocked in recirculating system of 4 rectangular tanks in a total volume of $1.2 \mathrm{~m}^{3}$ during 3 weeks for acclimatization of laboratory conditions, in a temperature-controlled room $26-28^{\circ} \mathrm{C}$ with lighting at a photoperiod of 14:10 light:dark cycle (Johnston et al. 2003; Olivotto et al. 2011; Dhaneesh et al. 2012a). Water quality was measured weekly, dissolved oxygen, temperature salinity and $\mathrm{pH}$, was measured with a multiparameter meter (YSI; Professional Plus; USA) and total ammonia, nitrite and nitrate was measured by photometric tests using NOVA $60 \mathrm{~A}$ Spectroquant ${ }^{\oplus}$ (Merck, Germany). Salinity was maintained at 33 ppt with the addition daily of freshwater using an osmoregulator (TMC,V2 Auto Top Up System, Bristol, UK) that provided automatic compensation of evaporated water with freshwater.

After the acclimatization period, the fish were divided for two experimental designs:

\section{Trial One - Effect of commercial diets}

The research setup of diets trials consisted of a recirculating system of twelve $15-\mathrm{L}(30 \cdot 20 \cdot 25 \mathrm{~cm}, \mathrm{~L} \cdot \mathrm{W} \cdot \mathrm{H})$ glass aquaria connected to a biological filter, a water pump, UV sterilizer and a sand filter, which was filled with filtered seawater. The flow rate into each aquarium was $45 \mathrm{Lh}^{-1}$. 180 fish were randomly sampled and measured and randomly distributed into twelve tanks at stocking density $1 \mathrm{fish}^{-1}$ of water (3 replicates for treatment). Fish were feed ad libitum three times daily with four different commercial granulate food with different crude protein levels, 52,5, 48, 41 and 38\% (Diet A, B, C and $\mathrm{D}$ ) during four months. The nutrient composition of the four diets are shown in Table 1. Gross energy content of the diets was calculated on the basis of their crude protein, total fat (ether extract) and nitrogen free extract (NFE) contents using the equivalents of 23.64, 39.54, and $17.15 \mathrm{MJkg}^{-1}$ (Ali et al. 2008). The identities of the products employed are not revealed to make any objective judgment of the findings. To standardize all diets and adapt de pellet size to the fish, all diets were mashed, and after passed thought different mesh- sieves to obtain pellets with 200 to $250 \mu \mathrm{m}$.

\section{Trial two - Effect of stocking density}

The research setup of stocking density trials consisted of a recirculation system of twelve $17-\mathrm{L}(30 \cdot 23 \cdot 25 \mathrm{~cm}$, $\mathrm{L} \cdot \mathrm{W} \cdot \mathrm{H})$ glass aquaria connected to a biological filter, a water pump, UV sterilizer and a sand filter, which was filled with filtered seawater. The flow rate into each aquarium was $50 \mathrm{Lh}^{-1}$.

330 fish were randomly sampled and measured and randomly distributed into twelve tanks at four different stock densities, $0.5,1,2$ and 3 fishL $^{-1}$ of water (3 replicates for treatment). Fish were feed ad libitum three daily with mix of four commercial granulate food (four diets used in experiment 1) during four months.

\begin{tabular}{|c|c|c|c|c|}
\hline Diets & A & B & $\mathrm{C}$ & D \\
\hline Crude protein & 52,5 & 48,0 & 41,1 & 38,1 \\
\hline Crude fat & 8,1 & 8,0 & 9,0 & 9,7 \\
\hline Moisture & 5,1 & 10,0 & 14,5 & 14,5 \\
\hline Fibre & 3,5 & $4,0,2,4$ & 2,8 & \\
\hline Nitrogen-free extract & 24,3 & 12,0 & 22,5 & 24,4 \\
\hline Ash & 6,5 & 18,0 & 10,5 & 10,5 \\
\hline Gross energy $\left(\mathrm{MJkg}^{-1}\right)$ & 19,8 & 16,6 & 17,1 & 17,0 \\
\hline Gross energy (kcalkg ${ }^{-1}$ ) & 4723,7 & 3956,5 & 4091,5 & 4066,0 \\
\hline $\mathrm{P} / \mathrm{E}$ (g protein $\mathrm{MJ}^{-1} \mathrm{GE}$ ) & 26,5 & 29,0 & 24,0 & 22,4 \\
\hline $\mathrm{P} / \mathrm{E}$ (mg protein $\mathrm{kcal}^{-1} \mathrm{GE}$ ) & 111,1 & 121,3 & 100,5 & 93,7 \\
\hline
\end{tabular}


During the experimental period the water quality was measured, maintained constant with normal parameters for maintaining this specie: $\mathrm{DO}>8.0, \mathrm{pH}$ between 8.0 and 8.4 temperature 26 to $28^{\circ} \mathrm{C}$, total ammonia and nitrite below $0.5 \mathrm{mgL}^{-1}$ and nitrate $<10 \mathrm{mgL}^{-1}$. At end of both trials all fish were individually anaesthetized with MS-222 $\left(90 \mathrm{mgL}^{-1}\right)$ to be sampled, weighed $(\mathrm{mg})$, measured $(\mathrm{cm})$, and the number of fish with miss-bands were recorded.

The influence of the diets and stocking density were evaluated by the mortality, specific growth rate (SGR \% length gain day $\left.^{-1}\right)^{1}$ and condition factor $(\mathrm{K})^{2}$.

$$
{ }^{1} \mathrm{SGR}=100(\text { In Lt-In Li) } / \mathrm{t}
$$

Where Li and Lt, are the initial and final body lengths and the $t$ is time in days.

$$
{ }^{2} \mathrm{~K}=100\left(\mathrm{~W} / \mathrm{L}^{3}\right)
$$

Where $\mathrm{W}$ is the final body weight $(\mathrm{mg})$ and $\mathrm{L}$ the final body length $(\mathrm{cm})$.

SGR was selected as the most appropriate growth measure as it is relative to initial body parameters and this standardisation best mitigates the effects of varying sizes of fish (Rushworth et al. 2011). In general SGR was calculated in base of weight gains, however generally ornamental species are sold per unit and graded by size rather than by weight, so we decide use fish growth performance in terms of size increment rather than weight. Condition factor is calculated from the relationship between the weight of a fish and its length (Sarkar et al. 2013).

Growth performance parameters are reported as means \pm standard error of mean (SEM) of average values per tank of each parameters. All data were checked for normality and homoscedasticity. A one-way analysis of variance (ANOVA) was used to determine significant differences of the effect of the experimental densities and diets (Zar 2009). Post hoc pairwise analysis (Tukey test) was conducted to determine significant differences among experimental combinations. When assumptions (that is, normality and homoscedasticity) were not met, Kruskal-Wallis, followed by Games-Howell test was employed as appropriate (Games and Howell 1976; Kirk 1982). For all statistical tests, the significance level was set at $\mathrm{p} \leq 0.05$. All calculations were performed with IBM SPSS Statistics 20.

\section{Results}

Trial one

The mean survival reached in groups feeding different diets varied between $68.89 \pm 2.22$ to $84.44 \pm 5.87 \%$, but no statistically differences were obtained ( $\mathrm{p}>0.05)$ (Figure 1A). Final lengths varied between $2.865 \pm 0.066$ to $3.108 \pm$ $0.066 \mathrm{~cm}$ and the $S G R$ varied from $0.340 \pm 0.016$ to
$0.485 \pm 0.001 \%$ cmday $^{-1}$, statistically differences were obtained, the higher SGR was obtained for diet C (ANOVA, $\mathrm{F}_{(3,8)}=18.41, \mathrm{p}=0.001$ ) (Figure 1B).

Condition factor c) and fish without miss-bands d) varied between $1.517 \pm 0.199$ to $2.651 \pm 0.47$ and $18.03 \pm 4.69$ to $26.92 \pm 5.18$, however, no differences were reach between the different commercial diets tested $(\mathrm{p}>0.05)$.

The best SGR was obtained with the $\operatorname{diet} \mathrm{C}$, and there was no significance differences in survival, fish without miss-bands or condition factor among diets during the experimental period.

\section{Trial two}

The survival varied between $82.5 \pm 1.9 \%$ to $100 \%$. The high survival rate was obtained for stocking density of 0.5 fishL $^{-1}$ (ANOVA, $F_{(3,8)}=13.240, p=0.001$ ) (Figure 2A). Final lengths of the fish stocked at a density of $0.5,1,2$ and 3 fishL $^{-1}$ reached means of $3.350 \pm 50.06,2.977 \pm$ $0.068,2.633 \pm 0.049$ and $2.612 \pm 0.04 \mathrm{~cm}$ respectively.

SGR varied between $0.237 \pm 0.013$ to $0.459 \pm 0.023 \%$ cmday $^{-1}$. The best SGR (Figure 2B) was obtained for stocking density of 0.5 fishL $^{-1}$ (ANOVA, $\mathrm{F}_{(3,8)}=36.99, \mathrm{p}=0.001$ ). Fish reared at 2 fishL $^{-1}$ obtained the best $\mathrm{K} 2.537 \pm 0.27$ (KruskalWallis, $\mathrm{K}=8,12, \mathrm{p}=0.034$ ) (Figure $2 \mathrm{C}$ ) and the maximum of fish without miss-bands (Figure 2D) were obtained at 0.5 fishL $^{-1}(58.33 \pm 4.16 \%)$ (ANOVA, $\mathrm{F}_{(3,8)}=15.28, \mathrm{p}=0.001$ ).

The best survival, SRG and the minimum percent of fish without miss-band was obtained for densities of 0,5 fishL ${ }^{-1}$, however, the best condition factor was obtained with stocking density of 2 fishL $^{-1}$.

\section{Discussion}

Stocking densities and ration size are two important factors affecting fish growth (Hernández et al. 2001; SalasLeiton et al. 2008; Saoud et al. 2008). In this study, the diets influence the specific growth rate, but not influence the survival, condition factor and fish without miss bands. No relation was observed between malpigmentations and the different types of diets tested. However, other studies demonstrated that polyunsatured fatty acids increase the development of a proper pigmentation (Avella et al. 2007). In case of the halibut and in the turbot, Bell et al. (2003) showed that a 2:1 ratio of DHA: EPA improves de dorsal pigmentation in this species.

In this study the use of diet $\mathrm{C}$ improve an increase of more than $0.49 \%$ cmday- 1 , comparatively to other rations tested. All diets under study have different level of crude protein and the best growth parameters was $\operatorname{diet} \mathrm{C}$, that have the second lowest level of crude protein $(41 \%)$, for some species increasing dietary protein can lead to improved fish production, especially in case of carnivorous fish, however the optimal protein requirements differ with fish species, size, water temperature, quality and diet formulation (Ali et al. 2008). 

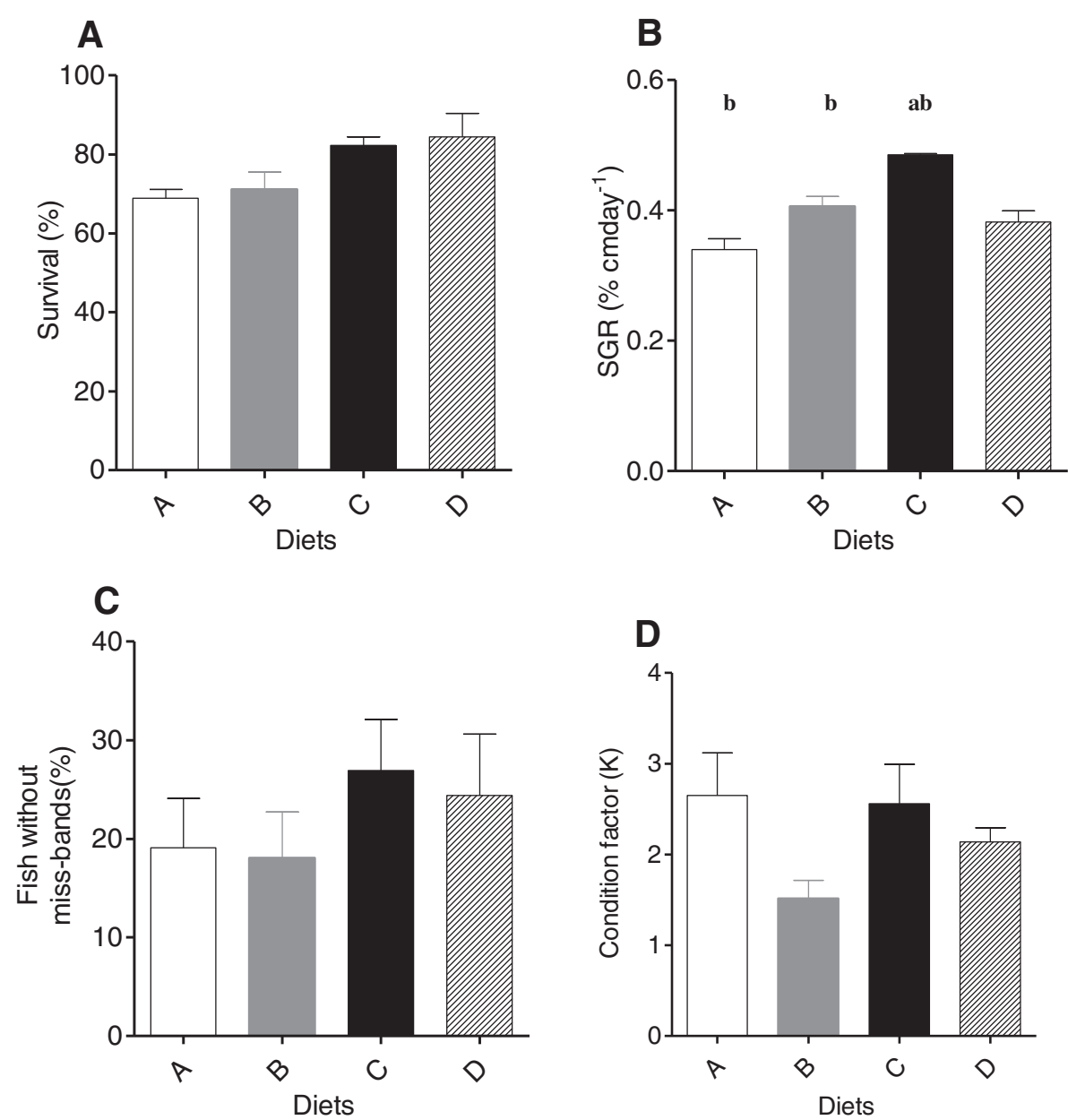

Figure 1 Effect of different diets composition on survival (A), specific growth rate (B), condition factor (C) and fish without miss-bands (D). Values are expressed by means of mean \pm SEM $(n=3)$. Lowercase represents significant statistical differences at level $p<0.05$ : (a) between diet $C$ and other diets; (b) between diet A and diets B and C.

Vijayagopal et al. (2008) reported the best for juvenile marine ornamental fish, striped damsel, Dascyllus aruanus using ration with crude protein between 360 and $470 \mathrm{~g} \mathrm{~kg}$, above and below this interval the SGR decreases. In generally $60 \%$ of production cost is relatively to the fish feed and protein is the component most expensive, optimizing dietary concentration is essential to increasing the profit of the fish culture, the results achieved with the diet $C$ corresponding to a huge improve on the mass scale production at end of one cycle production (Luo et al. 2004; Ghazala et al. 2011).

Stocking density is an area of particular concern in the welfare of intensively farmed fish (Ashley 2007; Wocher et al. 2011). In this experiment the survival, the specific growth rate and percentage of fish without miss-bands increase with decrease of stocking density.

Ornamental fishes with anomalous pigmentation, namely clownfishes with miss-bands have little demand in the ornamental market and are sold at a lowest prices
(Avella et al. 2007). Malpigmentation can caused by several environmental factors such as nutrition, substrate, density and light, but it is unclear the factors that affect malpigmentation, some authors revels that mechanisms of malpighmentation can be associated with stress of stocking density, in the wild olive flounder no phenomens of malpigmentaion are observed but is very common in domesticated flounder that are reared at high densities, (Kang and Kim 2013), our results are consistent with results reported by (Takahashi 1994) that suggested that abnormal pigmentation increases with stocking density.

The effect of stocking density on growth are in line with the view that in many cultured fish species growth is inversely related to stocking density and this is mainly attributed to social interactions, this is most special in clownfish that's lives in social groups based in size hierarchy (Colleye et al. 2009; Sánchez et al. 2010; Larsen et al. 2012). Clownfish controlling their size and growth 

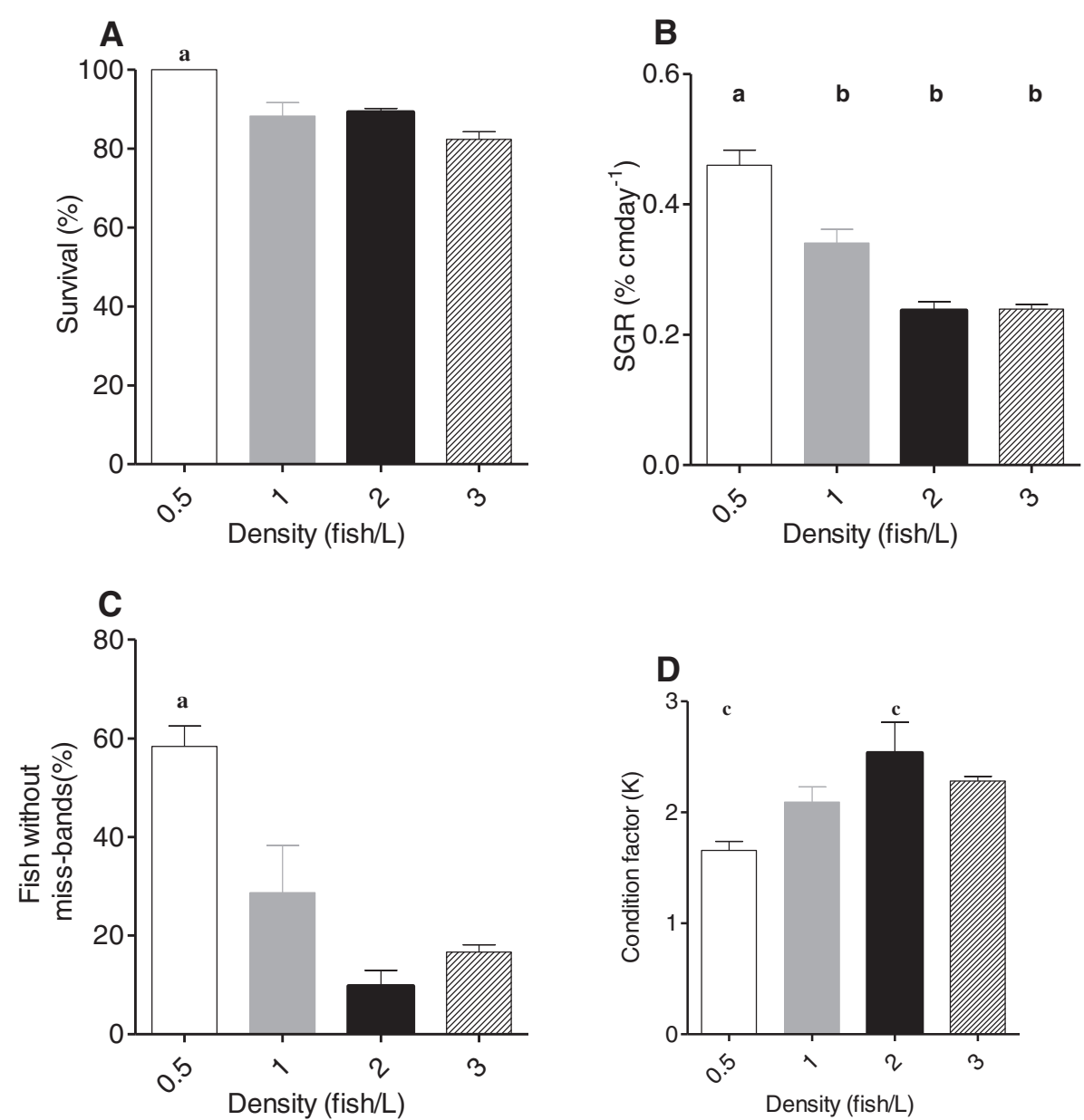

Figure 2 Effect of different stocking density on survival (A), specific growth rate (B), condition factor (C) and fish without miss-bands (D). Values are expressed by means of mean \pm SEM $(n=3)$. Lowercase represent statistical significant differences at level $p<0.05$ : (a) between 0.5 fishL ${ }^{-1}$ and the other stock densities; (b) between 1 fishL $^{-1}$ and 3 fishL ${ }^{-1}$; (c) between 0.5 and 2 fishL $^{-1}$.

rate according with their position in the group hierarchy (Buston 2003; Parmentier et al. 2009). However, the effect of stocking density can varied with the species, adverse effects on growth performance at high stocking densities were observed in juveniles bluegills (Lepomis macrochirus), amur sturgeon (Acipenser schrenckii), and nile tilapia (Oreochromis niloticus) (Yi and Kwei Lin 2001; Anderson et al. 2002; $\mathrm{Ni}$ et al. 2014). In contrast, null effects of high densities upon production were reported in juvenile cod (Ghadus morhua L.), european sea bass (Dicentrarchus labrax) and rainbow trout (Oncorhynchus mykiss) (Björnsson and Ólafsdóttir 2006; Lupatsch et al. 2010; McKenzie et al. 2012). Generally an increment of stocking density causes a deterioration of water quality and in poorly conditions fish grow less and die more and some authors use this explanation for the negative effect on growth performance at high stocking densities. Sometimes negative effects of high stocking density on fish growth and survival can be caused by deterioration of water quality, causing the increment of fish metabolites and carbon dioxide with reduction of $\mathrm{pH}$ level system (Ruyeta et al. 2007; Hosfeld et al. 2009). Nevertheless in this study the cause of SGR and survival decrease with increase of stocking density cannot be explained through a deterioration of water quality, since all treatments were insert in a same system (Ruyeta et al. 2007; Hosfeld et al. 2009).

The condition factor represents a quantitative indicator of the well-being of fish, and ornamental fish are judged for quality based on appearance and physical attributes (Moorhead and Zeng 2010; Guidelli et al. 2011). High condition factor values appears when fishes are on favourable environmental conditions, by contrast when fishes are in less favourable environmental conditions shows low values (Blackwell et al. 2000). Condition factor in our studies were similar to results obtained by Rushworth et al. (2011) in the culture of juvenile wideband anemonefish (Amphiprion latezonatus) at different temperatures. The results presented here clearly showed that in all treatments fish were on good conditions. 
Our results of survival and condition factor were similar to results obtained by (Johnston et al. (2003)) that studied the effect of different of ration size and feeding frequency on growth of juvenile Amphiprion percula.

Generally, the results suggest that stocking density have more effects comparing with effects of diets on specific growth rate, condition factor, the miss-band and survival of juvenile percula clownfish.

\section{Conclusions}

The production in captivity of ornamental fishes is the solution for to guarantee a long term sustainable trade and the way to preserve marine biodiversity.

This study defined optimal conditions helped for the production of this tropical coral reef ornamental fish in captivity, concerning anemonefishes husbandry in terms of survival and quality of fish pigmentation. It is believed that a compound diet of $41 \%$ protein would provide nutrients that will ensure optimal growth of $A$. percula, stocking density are critical and relevant point to enhance the captive production of tropical marine species for the aquarium trade. However the stock density that fish showed lowest malpigmentation is very lower to guarantee economic viability of mass production of this species, so more studies are necessary to turned profitable the mass production of this species.

\section{Competing interests}

The authors declare that they have no competing interests.

\section{Authors' contributions}

JC and VS was conceptualized and designed the study, carried out the experiments, drafted manuscript and participated in data analysis. SM, TB and RP supervised and approved the designed the study, statistical analysis and manuscript writing. All authors read and approved the final manuscript

Received: 28 October 2014 Accepted: 5 April 2015

Published online: 16 April 2015

\section{References}

Alcorn SW, Pascho RJ, Murray AL, Shearer KD (2003) Effects of ration level on immune functions in chinook salmon (Oncorhynchus tshawytscha). Aquaculture 217(1-4):529-545, doi:10.1016/S0044-8486(02)00369-1

Ali A, Al-Ogaily SM, Al-Asgah NA, Goddard JS, Ahmed SI (2008) Effect of feeding different protein to energy $(\mathrm{P} / \mathrm{E})$ ratios on the growth performance and body composition of Oreochromis niloticus fingerlings. J Appl Ichthyol 24(1):31-37, doi:10.1111/j.1439-0426.2007.00897.x

Anderson D, Saoud IP, Davis DA (2002) The effects of stocking density on survival, growth, condition, and feed efficiency of Bluegill Juveniles. N Am J Aquac 64(4):297-300, doi:10.1577/1548-8454(2002)064<0297:TEOSDO>2.0.CO;2

Araujo T, Miranda Fb, Chambel Jo, Mendes SLs, Baptista T, Pedrosa R (2014) The effects of food and photoperiod on strobilation of Aurelia aurita polyps. Frontiers in Marine Science. doi:10.3389/conf.FMARS.2014.02.00129

Ashley PJ (2007) Fish welfare: current issues in aquaculture. Appl Anim Behav Sci 104(3):199-235, doi:10.1016/j.applanim.2006.09.001

Avella MA, Olivotto I, Gioacchini G, Maradonna F, Carnevali O (2007) The role of fatty acids enrichments in the larviculture of false percula clownfish Amphiprion ocellaris. Aquaculture 273(1):87-95, doi:http://dx.doi.org/10.1016/j.aquaculture.2007.09.032

Avella MA, Olivotto I, Silvi S, Place AR, Carnevali O (2010) Effect of dietary probiotics on clownfish: a molecular approach to define how lactic acid bacteria modulate development in a marine fish. Am J Physiol Regul Integr Comp Physiol 298(2):R359-R371, doi:10.1152/ajpregu.00300.2009
Bell JG, McEvoy LA, Estevez A, Shields RJ, Sargent JR (2003) Optimising lipid nutrition in first-feeding flatfish larvae. Aquaculture 227(1-4):211-220, doi:10.1016/S0044-8486(03)00504-0

Björnsson B, Ólafsdóttir SR (2006) Effects of water quality and stocking density on growth performance of juvenile cod (Gadus morhua L.). ICES J Mar Sci 63(2):326-334, doi:10.1016/j.icesjms.2005.10.010

Blackwell BG, Brown ML, Willis DW (2000) Relative Weight (Wr) Status and current use in fisheries assessment and management. Rev Fish Sci 8:1-44

Buston P (2003) Social hierarchies: size and growth modification in clownfish. Nature 424(6945):145-146

Calado R (2006) Marine ornamental species from European waters: a valuable overlooked resource or a future threat for the conservation of marine ecosystems? Sci Mar 70:389-398

Chambel J, Pinho R, Sousa R, Ferreira T, Baptista T, Severiano V, Mendes S, Pedrosa R (2013) The efficacy of MS-222 as anaesthetic agent in four freshwater aquarium fish species. Aquaculture Research:n/a-n/a. doi:10.1111/are.12308

Chambel J, Costa R, Gomes M, Mendes S, Baptista T, Pedrosa R (2014) Hydrogen peroxide, iodine solution and methylene solution highly enhance the hatching rate of freshwater ornamental fish species. Aquacult Int:1-9. doi:10.1007/s10499-014-9779-1

Colleye O, Frederich B, Vandewalle P, Casadevall M, Parmentier E (2009) Agonistic sounds in the skunk clownfish Amphiprion akallopisos: size-related variation in acoustic features. J Fish Biol 75:908-916

Copeman LA, Parrish CC (2002) Lipid composition of malpigmented and normally pigmented newly settled yellowtail flounder, Limanda ferruginea (Storer). Aquac Res 33(15):1209-1219, doi:10.1046/j.1365-2109.2002.00761.x

de Oliveira EG, Pinheiro AB, de Oliveira VQ, da Silva Júnior ARM, de Moraes MG, Rocha ÍRCB, de Sousa RR, Costa FHF (2012) Effects of stocking density on the performance of juvenile pirarucu (Arapaima gigas) in cages. Aquaculture 370-371(0):96-101, doi:http://dx.doi.org/10.1016/j.aquaculture.2012.09.027

Dhaneesh K, Ajith Kumar T, Swagat G, Balasubramanian T (2012a) Breeding and mass scale rearing of clownfish Amphiprion percula: feeding and rearing in brackishwater. Chin J Ocean Limnol 30(4):528-534, doi:10.1007/s00343-012-1184-x

Dhaneesh KV, Nanthini Devi K, Ajith Kumar TT, Balasubramanian T, Tissera K (2012b) Breeding, embryonic development and salinity tolerance of Skunk clownfish Amphiprion akallopisos. J King Saud University - Science 24(3):201-209, doi:10.1016/j.jksus.2011.03.005

Ellis T, North B, Scott AP, Bromage NR, Porter M, Gadd D (2002) The relationships between stocking density and welfare in farmed rainbow trout. J Fish Biol 61(3):493-531, doi:10.1111/j.1095-8649.2002.tb00893.x

Erondu ES, Bekibela D, Gbulubo AT (2006) Optimum crude protein requirement of cat fish, Chrysichthys nigrodigitatus. J Fisheries Int 1:40-43

Games PA, Howell JF (1976) Pairwise multiple comparison procedures with unequal N's and/or variances: a Monte Carlo study. J Educ Stat 1:113-125

Gélineau A, Corraze G, Boujard T (1998) Effects of restricted ration, time-restricted access and reward level on voluntary food intake, growth and growth heterogeneity of rainbow trout (Oncorhynchus mykiss) fed on demand with selffeeders. Aquaculture 167(3-4):247-258, doi:10.1016/50044-8486(98)00320-2

Ghazala R, Tabinda AB, Yasar A (2011) Growth responses of juvenile grass carp (Ctenophartngodon idella) fed isocaloric diets with variable proteins levels. J Animal Plant Sci 21:850-856

Gomes LC, Chagas EC, Martins-Junior H, Roubach R, Ono EA, de Paula Lourenço JN (2006) Cage culture of tambaqui (Colossoma macropomum) in a central Amazon floodplain lake. Aquaculture 253(1-4):374-384, doi:10.1016/ j.aquaculture.2005.08.020

Guidelli G, Tavechio WLG, Takemoto RM, Pavanelli GC (2011) Relative condition factor and parasitism in anostomid fishes from the floodplain of the Upper Paraná River, Brazil. Vet Parasitol 177(1-2):145-151, doi:10.1016/j.vetpar. 2010.11.035

Hernández MD, Egea MA, Rueda FM, Aguado F, Martínez FJ, García B (2001) Effects of commercial diets with different P/E ratios on sharpsnout seabream (Diplodus puntazzo) growth and nutrient utilization. Aquaculture 195(3-4):321-329, doi:10.1016/S0044-8486(00)00564-0

Hosfeld CD, Hammer J, Handeland SO, Fivelstad S, Stefansson SO (2009) Effects of fish density on growth and smoltification in intensive production of Atlantic salmon (Salmo salar L.). Aquaculture 294(3-4):236-241, doi:10.1016/j.aquaculture.2009.06.003

Jamabo N, Keremah R (2009) Effects of stocking density on the growth and survival of the fingerlings of Clarias gariepinus (Burchell, 1822). J Fisheries Int $4: 55-57$ 
Johnston G, Kaiser H, Hecht T, Oellermann L (2003) Effect of ration size and feeding frequency on growth, size distribution and survival of juvenile clownfish, Amphiprion percula. J Appl Ichthyol 19(1):40-43, doi:10.1046/j.1439-0426.2003.00351.x

Kang DY, Kim HC (2013) Influence of density and background color to stress response, appetite, growth, and blind-side hypermelanosis of flounder, Paralichthys olivaceus. Fish Physiol Biochem 39(2):221-232, doi:10.1007/s10695-012-9693-2

Kirk RE (1982) Experimental design : procedures for the behavioral sciences. Brooks/Cole Pub. Co., Monterey, Calif

Kristiansen TS, Fernö A, Holm JC, Privitera L, Bakke S, Fosseidengen JE (2004) Swimming behaviour as an indicator of low growth rate and impaired welfare in Atlantic halibut (Hippoglossus hippoglossus L.) reared at three stocking densities. Aquaculture 230(1-4):137-151, doi:10.1016/S0044-8486(03)00436-8

Larsen BK, Skov PV, McKenzie DJ, Jokumsen A (2012) The effects of stocking density and low level sustained exercise on the energetic efficiency of rainbow trout (Oncorhynchus mykiss) reared at $190^{\circ} \mathrm{C}$. Aquaculture 324-325:226-233, doi:10.1016/j.aquaculture.2011.10.021

Leatherland JF, Cho CY (1985) Effect of rearing density on thyroid and interrenal gland activity and plasma and hepatic metabolite levels in rainbow trout, Salmo gairdneri Richardson. J Fish Biol 27(5):583-592, doi:10.1111/j.1095-8649.1985.tb03203.x

Luo Z, Liu YJ, Mai KS, Tian LX, Liu DH, Tan XY (2004) Optimal dietary protein requirement of grouper Epinephelus coioides juveniles fed isoenergetic diets in floating net cages. Aquac Nutr 10(4):247-252, doi:10.1111/j.1365-2095.2004.00296.x

Lupatsch I, Santos GA, Schrama JW, Verreth JAJ (2010) Effect of stocking density and feeding level on energy expenditure and stress responsiveness in European sea bass Dicentrarchus labrax. Aquaculture 298(3-4):245-250, http://dx.doi.org/doi:10.1016/j.aquaculture.2009.11.007

McKenzie DJ, Höglund E, Dupont-Prinet A, Larsen BK, Skov PV, Pedersen PB et al (2012) Effects of stocking density and sustained aerobic exercise on growth, energetics and welfare of rainbow trout. Aquaculture 338-341:216-222, doi:10.1016/j.aquaculture.2012.01.020

Moorhead JA, Zeng C (2010) Development of captive breeding techniques for marine ornamental fish: a review. Rev Fish Sci 18(4):315-343, doi:10.1080/10641262.2010.516035

Ni M, Wen H, Li J, Chi M, Bu Y, Ren Y et al (2014) The physiological performance and immune responses of juvenile Amur sturgeon (Acipenser schrenckii) to stocking density and hypoxia stress. Fish Shellfish Immun 36(2):325-335, http://dx.doi.org/10.1016/j.fsi.2013.12.002

Olivotto I, Di Stefano M, Rosetti S, Cossignani L, Pugnaloni A, Giantomassi F et al (2011) Live prey enrichment, with particular emphasis on HUFAs, as limiting factor in false percula clownfish (Amphiprion ocellaris, Pomacentridae) larval development and metamorphosis: molecular and biochemical implications. Comp Biochem Physiol A Mol Integr Physiol 159(3):207-218, doi:10.1016/j.cbpa.2011.02.004

Parmentier E, Colleye O, Mann D (2009) Hearing ability in three clownfish species. J Exp Biol 212(13):2023-2026, doi:10.1242/jeb.030270

Rowland SJ, Mifsud C, Nixon M, Boyd P (2006) Effects of stocking density on the performance of the Australian freshwater silver perch (Bidyanus bidyanus) in cages. Aquaculture 253(1-4):301-308, doi:10.1016/j.aquaculture.2005.04.049

Rushworth KJW, Smith SDA, Cowden KL, Purcell SW (2011) Optimal temperature for growth and condition of an endemic subtropical anemonefish. Aquaculture 318(3-4):479-482, http://dx.doi.org/10.1016/j.aquaculture.2011.06.004

Ruyeta JP-L, Bayon NL, Gros S (2007) How to assess fin damage in rainbow trout, Oncorhynchus mykiss? Aquat Living Resour 20:191-195, doi:10.1051/alr:2007031

Salas-Leiton E, Anguis V, Manchado M, Cañavate JP (2008) Growth, feeding and oxygen consumption of Senegalese sole (Solea senegalensis) juveniles stocked at different densities. Aquaculture 285(1-4):84-89, doi:10.1016/j.aquaculture.2008.08.001

Sánchez P, Ambrosio PP, Flos R (2010) Stocking density and sex influence individual growth of Senegalese sole (Solea senegalensis). Aquaculture 300(1-4):93-101, doi:10.1016/j.aquaculture.2009.12.013

Saoud IP, Ghanawi J, Lebbos N (2008) Effects of stocking density on the survival, growth, size variation and condition index of juvenile rabbitfish Siganus rivulatus. Aquacult Int 16(2):109-116, doi:10.1007/s10499-007-9129-7

Sarkar UK, Khan GE, Dabas A, Pathak AK, Mir Jl, Rebello SC et al (2013) Length weight relationship and condition factor of selected freshwater fish species found in river Ganga, Gomti and Rapti, India. J Environ Biol 34(5):951-956

Sharma JG, Chakrabarti R (1998) Effects of different stocking densities on survival and growth of grass carp, Ctenopharyngodon idella, larvae using a recirculating culture system. J Appl Aquac 8(3):79-83

Takahashi Y (1994) Influence of stocking density and food at late phase of larval period on hypermelanosis on the blind body side in juvenile Japanese flounder. Nippon Suisan Gakkaishi 60:593-598
Vijayagopal P, Gopakumar GN, Vijayan KK (2008) Empirical feed formulations for the marine ornamental fish, striped damsel, Dascyllus aruanus (Linné 1758) and their physical, chemical and nutritional evaluation. Aquac Res 39(15):1658-1665, doi:10.1111/j.1365-2109.2008.02039.x

Wocher H, Harsányi A, Schwarz FJ (2011) Husbandry conditions in burbot (Lota lota L.): impact of shelter availability and stocking density on growth and behaviour. Aquaculture 315(3-4):340-347, doi:10.1016/j.aquaculture.2011.01.051

Yang S-D, Lin T-S, Liou C-H, Peng H-K (2003) Influence of dietary protein levels on growth performance, carcass composition and liver lipid classes of juvenile Spinibarbus hollandi (Oshima). Aquac Res 34(8):661-666, doi:10.1046/j.1365-2109.2003.00880.x

Yi Y, Kwei Lin C (2001) Effects of biomass of caged Nile tilapia (Oreochromis niloticus) and aeration on the growth and yields in an integrated cage-cum-pond system. Aquaculture 195(3-4):253, doi:10.1016/S0044-8486(00)00558-5

Zar JH (2009) Biostatistical analysis. Pearson Education International, Upper Saddle River, NJ

Ziemann D (2001) The potential for the restoration of marine ornamental fish populations through hatchery releases. Aquar Sci Conserv 3(1-3):107-117, doi:10.1023/A:1011367615465

\section{Submit your manuscript to a SpringerOpen ${ }^{\odot}$ journal and benefit from:}

- Convenient online submission

Rigorous peer review

- Immediate publication on acceptance

- Open access: articles freely available online

- High visibility within the field

- Retaining the copyright to your article

Submit your next manuscript at $>$ springeropen.com 